Tersedia Online di http://journal2.um.ac.id/index.php/jmsp/

ISSN Online : 2541-4429

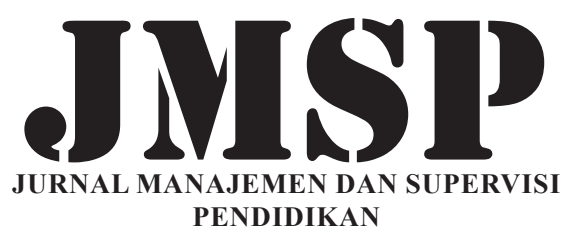

PENDIDIKAN

\title{
MENINGKATKAN KEMAMPUAN KOMUNIKASI DAN PEMECAHAN MASALAH MATEMATIKA MELALUI PEMBELAJARAN THINK-TALK- WRITE DALAM KELOMPOK KECIL
}

\author{
Agung Kridyastuti \\ SMPN 17 Kota Malang \\ J1. Pelabuhan Tanjung Priok 170 Kota Malang Jawa Timur Indonesia \\ agung.kridyastuti@gmail.com
}

\begin{abstract}
The selection of learning strategies is to create communication and problem solving, so that an effective learning will be obtained. This is intended to encourage student motivation in learning. One grouping students like is based on heterogeneity of students, so that in each group contain the smart students. It is hoped that those who are clever can help other students. One of the learning strategies used is to require students to engage in thinking, speaking, and writing (think - talk - write) in the learning process. Applying innovative learning as an alternative to solving problems in the mathematics learning Phitagoras Theorem. Some of the factors studied include: teacher factors, learning factors, student factors, increased communication and problem solving skills, and learning completeness. This research was carried out in three cycles. Each cycle consisted of planning, implementation, observation and reflection. After the research conducted, the results were obtained: cycle I did not succeed in making all students understand the concept. Learning activities from the first cycle to the third cycle run as planned; there is an increase in activity, communication and problem solving skills, and learning completeness in students.
\end{abstract}

Keywords: communication skills, problem solving, think-talk-write, small group

\begin{abstract}
Abstrak: Pemilihan strategi pembelajaran guna menciptakan komunikasi dan pemecahan masalah, sehingga akan diperoleh suatu pembelajaran yang efektif. Hal ini dimaksudkan untuk mendorong motivasi siswa dalam pembelajaran. Salah satu pengelompokkan yang disukai siswa adalah berdasarkan keheterogenan siswa, sehingga pada tiap-tiap kelompok terdapat siswa yang pandai. Diharapkan mereka yang pandai ini dapat membantu siswa lainnya yang kemampuannya lebih rendah.Salah satu strategi pembelajaran digunakan adalah mengharuskan siswa terlibat berpikir, berbicara, dan menulis (think-talk-write) dalam proses pembelajaran. Tujuan dari penelitian ini ditujukan untuk peningkatan kemapuan guru dalam menerapkan pembelajaran yang inovatif sebagai alternatif pemecahan masalah-masalah dalam pembelajaran matematika Teorema Phitagoras. Beberapa faktor yang diteliti antara lain: faktor guru, faktor pembelajaran, faktor siswa, peningkatan kemampuan komunikasi dan pemecahan masalah, serta ketuntasan belajar. Penelitian ini dilaksanakan dalam tiga siklus.Setiap siklus terdiri dari perencanaan, pelaksanaan, pengamatan dan refleksi. Setelah dilakukan penelitian didapatkan hasil: siklus I belum berhasil menjadikan semua siswa memahami konsep. Kegiatan pembelajaran sejak siklus pertama sampai siklus ketiga berjalan sesuai yang direncanakan; terdapat peningkatan aktivitas, kemampuan komunikasi dan pemecahan masalah, serta ketuntasan belajar pada para siswa.
\end{abstract}

Kata Kunci: kemampuan komunikasi, pemecahan masalah, think-talk-write, kelompok kecil

Komunikasi dan pemecahan masalah matematis merupakan bagian dari berpikir matematis tingkat tinggi yang bersifat kompleks, karena itu pembelajaran yang berfokus pada kemampuan tersebut memerlukan prasyarat konsep dan proses dari yang lebih rendah. Hal ini meliputi materi maupun cara mempelajari atau mengajarkannya. Untuk itu dalam pembelajaran perlu dipertimbangkan tugas matematika serta suasana belajar yang mendukung untuk mendorong kemampuan tersebut. Pertimbangan ini menyangkut pengambilan keputusan pembelajaran yang digunakan di kelas yang diambil oleh guru. Kondisi pembelajaran 
dimana siswa belajar secara pasif, jelas tidak menguntungkan terhadap hasil belajarnya.Untuk itu perlu usaha guru agar siswa belajar secara aktif.

Sejalan dengan pendapat diatas, Sumarmo (2000) mengatakan agar pembelajaran dapat memaksimalkan proses dan hasil belajar matematika, guru perlu mendorong siswa untuk terlibat secara aktif dalam diskusi, bertanya serta menjawab pertanyaan, berpikir secara kritis, menjelaskan setiap jawaban yang diberikan, serta mengajukan alasan untuk setiap jawaban yang diajukan. Malone dan Krismanto (1997) mengatakan penggunaan kegiatan kelompok dalam belajar matematika direkomendasikan secara tinggi.Hal ini dimaksudkan untuk mendorong motivasi siswa dalam pembelajaran. Salah satu cara pengelompokkan yang disukai siswa adalah berdasarkan keheterogenan siswa, sehingga pada tiap-tiap kelompok terdapat siswa yang pandai. Diharapkan mereka yang pandai ini dapat membantu siswa lainnya yang kemampuannya lebih rendah.

Dengan mempertimbangkan beberapa pendapat di atas, penulis melakukan sebuah penelitian kolaboratif bersama guru-guru matematika di lingkungan SMP Negeri 17 Kota Malang, dengan judul "Meningkatkan Kemampuan Komunikasi dan Pemecahan Masalah Matematika Teorema Phytagoras Melalui Pembelajaran Think-Talk-Write dalam Kelompok Kecil pada SMP Negeri 17 Malang". Strategi pembelajaran yang digunakan ini mengharuskan siswa terlibat berpikir, berbicara, dan menulis dalam proses pembelajaran.

Sedangkan model yang dipilih adalah pembelajaran dalam kelompok kecil dengan anggota 4 sampai 6 orang siswa yang dikelompokkan secara heterogen menurut kemampuan matematikanya. Pengelompokkan seperti ini dimaksudkan agar semua siswa terlibat secara aktif dalam proses pembelajaran. Tujuan dari penelitian ini ditujukan untuk peningkatan kemapuan guru dalam menerapkan pembelajaran yang inovatif dengan strategi think - talk - write dalam kelompok kecil sebagai alternatif pemecahan masalah-masalah dalam pembelajaran matematika Teorema Phitagoras. Tujuan selanjutnya adalah Meningkatkan kemampuan komunikasi dan pemecahan masalah matematika teorema Phytagoras siswa.

\section{METODE}

Penelitian tindakan ini dilaksanakan di SMP Negeri 17 Malang pada Kelas VIII-B yang jumlah siswanya 31 orang, terdiri dari 16 perempuan dan 15 laki-laki. Penelitian ini berlangsung pada semester kedua Tahun Pelajaran 2017/2018. Siswa yang menjadi subyek penelitian memiliki karakteristik yang beragam, baik dari segi kemampuan, motivasi maupun latar belakang pengetahuannya. Itulah sebabnya penulis tertarik melakukan penelitian pada kelas tersebut.

Penelitian ini dilaksanakan dalam tiga siklus.Setiap siklus terdiri dari perencanaan, pelaksanaan, pengamatan dan refleksi. Kegiatan pada masing-masing siklus diuraikan secara singkat berikut ini:

\section{Siklus Pertama}

Kegiatan perencanaan pada siklus pertama adalah tim peneliti berkolaborasi dengan guru matematika dalam mengembangkan scenario pembelajaran dengan strategi think-talk-write. Selanjutnya tahap pelaksanaan pembelajaran. Pada tahap ini siswa belum terbiasa dengan strategi think-talk-write.Masih banyak yang terlihat kebingungan dan menjawab pertanyaanpertanyaan sekenanya. Beberapa siswa (sekitar10\%) mulai menyesuaikan diri dengan cara belajar "baru" ini, tetapi masih gagal dalam memberikan respon yang diinginkan. Selanjutnya kekurangan-kekurangan tersebut menjadi bahan untuk perbaikan pada siklus selanjutnya.Hasil formatif siswa menunjukkan bahwa upaya memperbaiki kemampuan komunikasi dan pemecahan masalah siswa masih terhambat karena pembelajaran dengan strategi think-talkwrite tidak familiar dengan siswa.

\section{Siklus Kedua}

Pada siklus kedua dilakukan perbaikan dalam perencanaan dan pelaksanaan pembelajaran. Suasana kompetisi dalam memberikan penyelesaian masalah dalam setiap kelompok mulai muncul. Setiap siswa yang berusaha mengemukakan pendapatnya diberi penghargaan dengan memberi perhatian dan meminta temannya untuk memberikan pendapatnya. Suasana belajar mulai hidup dan siswa mulai terbiasa dengan belajar berkelompok dan mengemukakan pendapat. Dari setiap kelompok diskusi mulai dihasilkan berbagai 
alternatif jawaban yang cukup kreatif. Pada tahap ini hasil tes kemampuan komunikasi dan pemecahan masalah siswa meningkat walaupun belum merata.

\section{Siklus Ketiga}

Berdasarkan hasil refleksi dari kegiatan pembelajaran pada siklus kedua, maka perencanaan dan pelaksanaan pembelajaran pada siklus ketiga diarahkan untuk semakin meningkatkan kemampuan komunikasi dan pemecahan masalah matematika. Masalahmasalah semakin dibuat sulit agar siswa tertantang untuk mengerahkan segala kemampuan matematiknya untuk dapat menjawab masalah tersebut. Siswa nampak mulai aktif dalam diskusi setiap kali dihadapkan pada masalah. Siswa diminta membandingkan dan mendiskusikan hasil pekerjaannya dengan siswa lain, baik secara perorangan maupun kelompok. Hasil tes kemampuan komunikasi dan pemecahan masalah matematika siswa pada siklus ini meningkat seperti yang diharapkan.

\section{HASIL DAN PEMBAHASAN}

\section{Hasil}

Pada siklus pertama, tim peneliti belum berhasil menjadikan semua siswa memahami konsep. Tetapi kegiatan membimbing dan memotivasi siswa sudah mulai terlihat hasilnya. Penanaman konsep pada siklus kedua dan ketiga lebih ditingkatkan lagi dengan tidak mengurangi kegiatan membimbing dan memotivasi siswa. Kegiatan pembelajaran sejak siklus pertama sampai siklus ketiga berjalan sesuai yang direncanakan, meskipun ada hambatan dari siswa karena masalah kebiasaan. Hasil pengamatan terhadap aktifitas siswa selama berlangsungnya kegiatan penelitian dapat dilihat pada Tabel 1. Kemampuan komunikasi dan pemecahan masalah matematika siswa berdasarkan hasil tes selama tiga siklus dapat dilihat pada gambar 1 . Ketuntasan belajar siswa selama tiga siklus dapat dilihat pada gambar 2

Tabel 1. Aktifitas Siswa dalam Pembelajaran Think-Talk-Write dalam Kelompok Kecil

\begin{tabular}{|c|c|c|c|c|c|c|c|c|c|c|}
\hline \multirow{2}{*}{ No } & \multirow{2}{*}{ Aspek yang Diamati } & \multicolumn{3}{|c|}{ Silus I } & \multicolumn{3}{|c|}{ Siklus II } & \multicolumn{3}{|c|}{ Siklus III } \\
\hline & & B & $\mathbf{C}$ & $\mathbf{K}$ & B & $\mathbf{C}$ & $\mathbf{K}$ & B & C & $\mathbf{K}$ \\
\hline \multirow[t]{3}{*}{1} & $\begin{array}{l}\text { Think: Membaca dan mencari informasi yang } \\
\text { berkenaan dengan tugas. }\end{array}$ & $\mathrm{v}$ & & & $\mathrm{v}$ & & & $\mathrm{v}$ & & \\
\hline & Talk: & & & & & & & & & \\
\hline & $\begin{array}{l}\text { a) Mengajukan pertanyaan/ Mengemukakan } \\
\text { pendapat/ Menanggapi pendapat }\end{array}$ & & $\mathrm{v}$ & & & $\mathrm{v}$ & & $\mathrm{v}$ & & \\
\hline \multirow[t]{3}{*}{2} & $\begin{array}{l}\text { b) Mencari informasi yang berkenaan dengan } \\
\text { tugas (bertanya dan membaca) }\end{array}$ & & $\mathrm{V}$ & & & $\mathrm{V}$ & & $\mathrm{v}$ & & \\
\hline & c) Penyelesaian tugas & & & $\mathrm{v}$ & & $\mathrm{v}$ & & $\mathrm{v}$ & & \\
\hline & $\begin{array}{l}\text { d) Keterlibatan anggota dalam kegiatan Ke- } \\
\text { lompok }\end{array}$ & & & $\mathrm{v}$ & & $\mathrm{v}$ & & $\mathrm{v}$ & & \\
\hline 3 & Write: Menulis & & & $\mathrm{v}$ & & $\mathrm{v}$ & & $\mathrm{v}$ & & \\
\hline
\end{tabular}

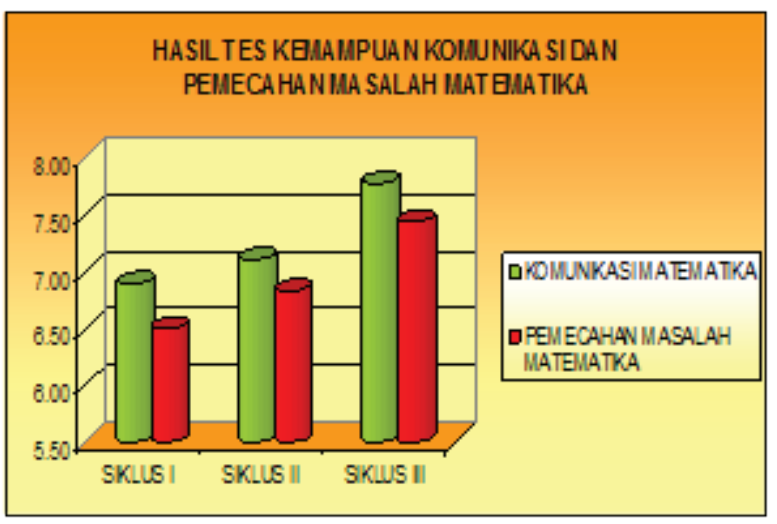

Gambar 1 Diagram Kemampuan Komunikasi 


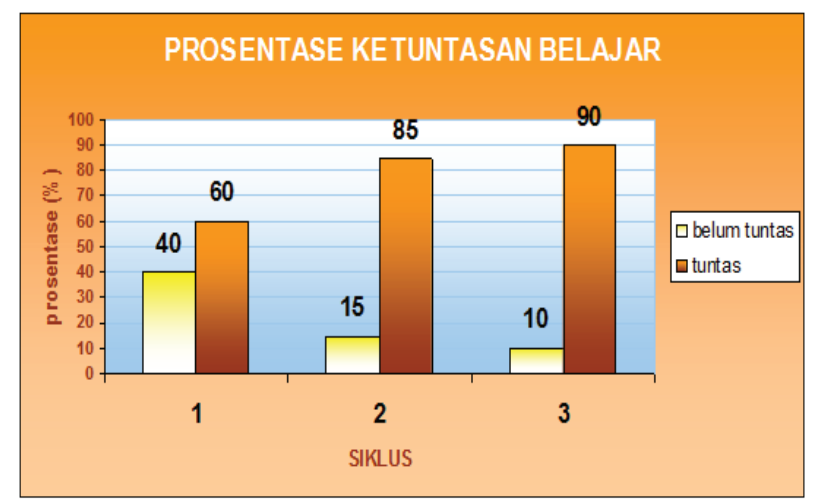

\section{Gambar 2 Diagram Ketuntasan Belajar dan Pemecahan Masalah Matematika}

\section{Pembahasan}

Berdasarkan hasil pengumpulan data secara sederhana, maka beberapa hal yang terungkap dalam penelitian ini dikaji kesesuaian nya dengan langkah-langkah penerapan strategi think-talkwrite, sebagai berikut:

Pelaksanaan penelitian dibagi menjadi tiga siklus, dimana terdapat perbaikan pencapaian hasil belajar dengan semakin meningkatnya siklus. Metode serupa juga digunakan oleh Azrah (2017) dan didapatkan hasil yang serupa yakni terjadi perbaikan hasil belajar pada siklus berikutnya. Azrah juga menyatakan bahwa berdasarkan analisis aktivitas guru dan siswa dapat dikatakan bahwa penerapan startegi thinktalk-write (TTW) dalam pembelajaran kooperatif semakin sesuai dengan dengan rencana pelaksanaan pembelajaran (RPP) dan proses pembelajaran juga semakin membaik.

Siswa berpartisipasi lebih aktif dalam pelajaran dan lebih mudah mengungkapkan ide-idenya. Pembelajaran dengan strategi thinktalk-write membuat suasana pembelajaran yang bebas, responsif, dan mendukung karena banyak jawaban benar sehingga setiap siswa memiliki kesempatan untuk memperoleh jawaban sendiri. Karena siswa sangat aktif maka hal tersebut membawa semua siswa pada diskusi kelas yang menarik.

Kondisi ini dapat dicapai karena model pembelajaran think-talk-write merupakan pembelajaran yang kooperatif. Strategi pembelajaran ini pada dasarnya pembelajaran ini dibangun melalui proses berpikir, berbicara dan menulis. Dan merupakan salah satu dari tipe pembelajaran kooperatif (Yamin, 2008). Menurut Azrah (2017) dalam artikelnya menyebutkan pembelajaran kooperatif merujuk pada berbagai macam metode pengajaran dimana para siswa bekerja dalam kelompok-kelompok kecil untuk saling membantu satu sama lainnya dalam mempelajari materi pelajaran.

Hasil temuan yang sama juga dikemukanan oleh Azrah (2017), yakni hasil belajar matematika siswa mengalami peningkatan dengan strategi pembelajaran think-talk-write. Siswa memiliki lebih banyak kesempatan untuk menggunakan pengetahuan dan keterampilan matematiknya secara komprehensif. Karena banyak solusi berbeda maka semua siswa dapat memilih cara yang paling mereka sukai dan memunculkan ide merekasendiriuntukmenyelesaikan soal. Menurut Yamin (2008) model pembelajaran Think-TalkWrite (TTW) membangun pemikiran, merefleksi, dan mengorganisasi ide, kemudian menguji ide tersebut sebelum peserta didik diharapkan untuk menulis. Alur model pembelajaran Think-TalkWrite (TTW) dimulai dari keterlibatan peserta didik dalam berpikir atau berdialog reflektif dengan dirinya sendiri, selanjutnya berbicara dan berbagi ide dengan temannya, sebelum peserta didik menulis. Sedangkan menurut Azrah (2017) penerapan strategi Think - Talk - Write (TTW) merupakan pendekatan yang selalu dikembangkan dalam proses pembelajaran yang dapat mengaktifkan dan menimbulkan inkuiri siswa dalam menyelesaikan materi pembelajaran.

Setiap siswa dapat merespon soal dalam beberapa cara berbeda menurut caranya sendiri 
meskipun berada dalam suatu kelompok kecil. Arend dalam Trianto (2012) menyatakan ciri pembelajaran kooperatif adalah: (a) siswa bekerja dalam kelompok secara kooperatif untuk menuntaskan materi belajar; (b) kelompok dibentuk dari siswa yang berkemampuan tinggi, sedang dan rendah; (c) bila memungkinkan, anggota berasal dari ras, budaya, suku dan jenis yang beragam; dan (d) penghargaan lebih berorientasi pada kelompok dari pada individu. Hasil temuan juga menunjukkan banyaknya siswa yang menjawab benar dengan alasan yang benar semakin meningkat.

Pembelajaran dengan strategithink-talk-write memberikan siswa pengalaman bernalar melalui kegiatan membandingkan dan diskusi dalam kelas, sehingga siswa sangat termotivasi untuk memberikan alasan dari jawaban-jawabannya kapada siswa-siswa lain. Kegiatan ini merupakan kesempatan yang penting untuk mengembangkan cara berpikir mereka. Karena proses berpikir dan berbicara atau diskusi merupakan langkah penting dalam proses membawa pemahaman siswa (Huinker dan Laughlin, 1996). Terjadi penambahan pengalaman bagi siswa untuk menikmati kesenangan menemukan dan menerima persetujuan dari teman sekelasnya. Karena siswa memiliki jawaban sendiri maka siswa akan tertarik untuk mengetahui jawaban teman-temannya. Sebagaimana dinyatakan Slameto (2010) bahwa belajar adalah suatu proses usaha yang dilakukan seseorang untuk memperoleh suatu perubahan tingkah laku yang baru secara keseluruhan sebagai hasil pengalaman sendiri dalam interaksi lingkungan.

\section{SIMPULAN}

Berdasarkan hasil penelitian tindakan kelas dan pembahasan hasil pengamatan yang dilaksanakan, dapat disimpulkan bahwa kemampuan komunikasi dan pemecahan masalah matematika siswa meningkat setelah mendapatkan pembelajaran dengan strategi Think-Talk-Write dalam Kelompok Kecil. Disamping itu Meningkatnya kemampuan komunikasi dan pemecahan masalah matematika mengoptimalkan prestasi belajar matematika siswa.
Pembelajaran dengan strategi ThinkTalk-Write dalam Kelompok Kecil adalah pembelajaran yang bernafaskan konstruktivisme. Menurut faham ini, ilmu pengetahuan dibangun sendiri oleh siswa dan bukan dipindahkan begitu saja dari guru ke siswa. Oleh karena itu, pendekatan pembelajaran ini sangat cocok dilakukan di kelas untuk membantu siswa membangun pengetahuannya. Pembelajaran ini tidak membutuhkan biaya seperti halnya bentuk-bentuk pembelajaran lainnya, hanya saja diperlukan persiapan yang matang terutama dalam hal mengembangkan soal-soal contoh dan latihan. Penerapan pembelajaran dengan Pembelajaran dengan strategi Think-Talk-Write dalam Kelompok Kecil ini memungkinkan untuk diterapkan pada mata pelajaran lain selain matematika. Hasil penelitian ini hendaknya menjadi sumber inspirasi bagi guru untuk lebih meningkatkan mutu pembelajaran disekolah. Sedangkan bagi sekolah, hendaknya dapat diterapkan strategi pembelajaran yang inovatif agar diperoleh hasil belajar yang berkualitas.

\section{DAFTAR RUJUKAN}

Azrah, M. 2017. Penerapan Strategi Think-Talk-Write (Ttw) Dalam Pembelajaran Kooperatif Untuk meningkatkan Hasil Belajar Matematika Siswa Kelas III SD Negeri 009 Tembilahan. Jurnal Primary Program Studi PGSD Fakultas Keguruan dan Ilmu Pendidikan Universitas Riau. Vol 6 [1]

Huinker, D. dan Laughlin, C. 1996. "Talk Your Way into Writing". Dalam Communication in Mathematicss K-12 and Beyond, 1996 year book. National Council of Teachers of Mathematics.

Malone, J.A. dan Krismanto, A. 1997. "Indonesian Students' Attitudes and Perceptions Towards Small-Group Work in Mathematics". Journal of Science and Mathematics Educations in Southeast Asia.XVI (2). 97-103

Malone, J.A. dan Krismanto, A. 1997. "Indonesian Students' Attitudes and Perceptions Towards Small-Group Work in Mathematics". Journal of Science and Mathematics Educations in Southeast Asia.XVI (2). 97-103

Slameto. 2010. Belajar dan Faktor-Faktor yang Mempengaruhinya. Jakarta. Rineka Cipta Karya

Sumarmo, U. 2000. Pengembangan Model Pembelajaran Matematika untuk Meningkatkan 
Kemampuan Intelektual Tingkat Tinggi Siswa Sekolah Dasar. Laporan Penelitian. Bandung: Lembaga Penelitian UPI.

Sumarmo, U. 2000. Pengembangan Model Pembelajaran Matematika untuk Meningkatkan Kemampuan Intelektual Tingkat Tinggi Siswa Sekolah Dasar. Laporan Penelitian. Bandung: Lembaga Penelitian UPI.
Trianto. 2012. Mendesain Model Pembelajaran Inovatif Progresif. Jakarta. Kencana Prenada Media Group.

Yamin, M., dan Bansu I. Ansari. 2008. Taktik Mengembangkan Kemampuan Individual Siswa. Jakarta: Gaung Persada Press Jakarta 